Brit. J. industr. Med., 1963, 20, 210.

\title{
AN ACCOUNT OF THE FOUNDING OF H.M. INSPECTORATE OF MINES AND THE WORK OF THE FIRST INSPECTOR HUGH SEYMOUR TREMENHEERE
}

\author{
BY
}

\author{
O. P. EDMONDS and E. L. EDMONDS
}

(RECEIVED FOR PUBLICATION FEBRUARY 21, 1963)

\begin{abstract}
This paper refers briefly to the adverse environmental conditions in mines in the middle of the nineteenth century and the first attempts made by the central government to remedy them. The life, character, and contribution of Hugh Seymour Tremenheere, the first inspector, is described in some detail.
\end{abstract}

There is considerable information about the origin of H.M. Inspectorate of Mines scattered throughout the reports of the many Royal Commissions which have investigated the industry. Such information is normally in the form of a bare chronological recital of events with special emphasis on legislation. Other accounts are few and, with the exception of Boyd (1879), consist similarly of short historical summaries (Bryan, 1950; Morrah, 1927; and Bridgmore Brown, 1960). Yet no institution grows successfully from a welter of blue print documents. The present-day organization of a complement of 185 inspectors into neat regions covering the main coalfields with a central headquarters in London and their well-defined duties and responsibilities to each other, to management and to men, have been formulated as a result of the practical experience of individual inspectors about whom we know little. The creative contribution of the early inspectors to this behaviour pattern is especially great as their mandate was vague and opportunity for exercise of personal discretion was inevitably greater. This paper evaluates the work of Hugh Seymour Tremenheere, the first inspector, and is based largely on his publications, his private papers, and his diaries. It is necessary, of course, to refer briefly to conditions and events in the mining industry prior to his appointment in 1843.

\section{Environmental Conditions in Coal and Iron Mines}

Coal was first mined in this country in 1200 but by the sixteenth century all the main coalfields were being developed. Newcommen's atmospheric engine in the early eighteenth century, the use of coal to make iron in 1740, and then Watt's steam engine gave impetus to both coal and iron mining and the first drift northwards across a line joining Southampton and Hull, which formerly contained the main bulk of the population. Estimates from the census of 1841 show about 115,000 men, 41,000 boys under the age of 20 , and 4,000 females employed in coal and iron mines.

The deepest mine at this time $(2,145 \mathrm{ft}$.; $653.8 \mathrm{~m}$. deep) was at Apedale in north Staffordshire but most were appreciably less deep. The shafts varied in width from $4 \mathrm{ft}$. $(1.22 \mathrm{~m}$.) to $5 \mathrm{ft}$. $(1.52 \mathrm{~m}$.) in some pits to, more rarely, $15 \mathrm{ft}$. $(4.57 \mathrm{~m}$. $)$. Seam thicknesses, as today, were 18 in. $(0.457 \mathrm{~m}$.) in parts rising to $9 \mathrm{ft}$. $(2.895 \mathrm{~m}$.) in others. There is no accurate figure for the number of pits, but in 1853 an approximate total of 2,500 can be derived from inspectors' correspondence with the Home Office.

Violent explosions were described in Philosophical Transactions at the end of the seventeenth century (Boyd, 1879; Buess, 1962) and these increased in number and severity. Many more men died in ones and twos less dramatically in everyday incidents; between 1851 and 1860 approximately 1,000 died each year, about one in 245 miners compared with one in 2,000 today. Apart from mutilation by accident, there were other health hazards, asphyxiation, shortened expectation of life, deformity, and pulmonary disease. As in factories, however, it was the impact of these harsh environmental conditions on women and children who worked underground which received most emphasis. E. Carlton Tufnell, 
while reporting on factories in Lancashire in 1833, incidentally descended the Worsley mine and he gives a first-hand account of boys and girls dragging from the coal-face 4-cwt. buckets harnessed to the body by chain and belt. This method was in fact still in use in 1926 in Somerset. He concludes, "It must appear to every impartial judge of the two occupations that the hardest labour in the worst room of the worst conducted factory is less hard, less cruel and less demoralising than the labour in the best of coalmines".

\section{Early Attempts at Remedy}

Just as the initiative to remedy adverse conditions in factories came from without the industry through public-spirited humanitarian citizens like Dr. Perceval, so in coal-mines, following a terrible explosion at Felling Colliery when 92 lives were lost, the Sunderland Society was formed in 1812. Its members included the Dean and Chapter of Durham, representatives of the Bar, the peerage, and the medical profession. This society persuaded local magistrates to hold inquests on all colliery deaths and obtained the service of Humphrey Davy who later produced the safety lamp. A similar private society was formed in 1839 in South Shields following disasters at Springville and St. Hilda, where 81 were killed. They laboured unceasingly for three years and although, as Sir Andrew Bryan (1950) points out, there was no mining engineer on the committee, they did visit colliers and earned the approbation of Matthias Dunn (1854), later to be appointed inspector under the Coal Mines Act of 1850 .

The report was published in 1842 and contains voluminous information on safety lamps, ventilation, employment of boys underground, plans, maps, scientific education of colliery officials, and medical treatment after explosion. Government inspection is strongly recommended in order to reduce accidents and stimulate the introduction by colliery managers of safer mining practices.

Apart from these private committees some fact finding had been initiated by the government. A Select Committee of both Houses in 1829 had been appointed to assess the risks of investment in coal-mining, and another in 1835 which investigated the frequent fatal accidents. At the latter enquiry George Stephenson, of locomotive fame, had recommended that central inspectors should be given the powers to halt the working of a colliery if necessary, and the renowned John Buddle favoured casual inspection by mining engineers acting in an advisory capacity only. The report, published on June 2, admitted "failing in obtaining accurate information" and recommended that "men of known ability be encouraged to visit mines, whether in the character of distinguished scientists, chemists, mechanists or philanthropists". In 1840 at Lord Ashley's instigation there was a Royal Commission on the employment of children in coal-mines. This report, accompanied by graphic pictures, confirmed the findings of Tufnell in 1833. In 1842, following riots, the "Midland Commission" investigated in particular the Butty system and exposed the flagrant disregard for the Truck Act.

Few practical measures had ever been taken. John Buddle in 1834 at a meeting of the Natural History Society in Newcastle, and Thomas Sopwith at a meeting of the British Society for the Advancement of Science, had both recommended national registration of the plans of disused, abandoned collieries, and in 1839 a Mining Record Office was opened in London for this purpose. T.B. Jordan was nominated as first keeper of the Mining Records in 1840 , but since the system was entirely voluntary until 1872, it was not effective.

The government in 1800 still regarded miners as rather special types of criminals and an enactment of that year imposed severe penalties on them for destruction of colliery property and breach of their bond of employment (a civil offence elsewhere). For the next 42 years there was no effective legislation at all due to the dominance of the doctrine of laissezfaire. Then mounting public indignation moved Lord Ashley to introduce his bill and on August 10, 1842 an Act of Parliament received Royal Assent which prohibited women and boys under the age of 10 from working underground, stopped the payment of wages in public houses, and prescribed a minimum age of 15 for winding engine-men. The Secretary of State was given authority to appoint an inspector with power of entry into collieries at all times who would report on the condition of the people employed therein and whether the Act was being observed. Unlike the earlier Factory Act of 1833, no powers of enforcement were given to the inspector or indeed to anyone else. Informers were to receive half the fine levied. H. Manners Sutton, an Under Secretary for State, however, in the letter of appointment to Tremenheere dated December 14, 1843, adds to the duties of inquiry and reporting a request to "take such steps as may be within your power to secure to the labourers employed in mines and collieries the benefits guaranteed to them by parliament and to bring to Justice those who by stealth violate the law". With this rather vague mandate Tremenheere evolved a pattern of work for the inspector, and the extent to which this has survived is a useful measure of his contribution to H.M. Inspectorate of Mines and Quarries. Appreciation of his method is considerably helped by brief reference to his earlier career and background. 


\section{Character and Training}

Hugh Seymour Tremenheere was born in 1802 into a wealthy and well established family with a long tradition of public service (Tremenheere, 1925). His education was characteristic of his patrician classpreparatory school, Winchester, and New College, Oxford, rounded off by two grand tours, one of England and Scotland and one of Europe, lasting two years. He was called to the Bar in 1834 and practised on the western circuit for five years. Head of his school and gold medallist, his attainment was based on an infinite capacity for hard work rather than brilliance, e.g. he thought little of learning by heart 600 lines of Latin verse per week. This early indoctrination in the classics had a profound influence. His concept of good government, about which he wrote frequently, is based on the experience of the Greeks; for him each class of society had privileges and duties but these were neither similar nor equal (Tremenheere, $1852 a, b ; 1854 ; 1883 ; 1891 ; 1893$ ). His translation of Pindar's Odes (1866) provides the motif for his own devotion to public service. "The shepherd, the ploughman, the fowler, the seaman, are paid by money; their object is to appease hunger; but he who has gained honour in the public games or in battle receives his greatest reverence in the praises of his fellow countrymen." Classical rationalism and distrust of emotion were endorsed by his legal training. It is not surprising that in his early papers to the Edinburgh Review he commented on "the power of the priesthood in inverse relationship to the spirit of inquiry;" or that his first reaction when his affianced ran off with another was to "fly to the country to regain my calmness of mind". In character he married at the age of 54 the widow of Vicesimus Knox, Deputy Speaker of the House of Commons.

Physical violence, which is so often emotive in origin, was therefore distasteful to him but this should not be thought a lack of courage. He did not hesitate to vote solely against a motion for universal suffrage at a meeting of Radicals in London despite the fact that he thereby was inviting physical injury. Such a man was clearly able to deliver analytical papers to the newly formed Royal Statistical Society, and in a presidential address to the Royal Geological Society of Cornwall he pointed out that "step by step, by patient investigation with careful comparison man gets glimpses of the laws governing change". This method characterizes his own investigations and he strove to behave as one, in his own words, "accustomed uniformly to put aside all narrow feelings, to smooth down all possible asperities". He was, however, no desiccated coco-nut and was capable of strong feeling even though rarely expres- sed, e.g. his condemnation of Gladstone for his Irish policy is particularly trenchant (Tremenheere, 1888).

He also castigated the press on several occasions for their emotional and distorted accounts of public incidents (Tremenheere, 1852b). Nevertheless, his official reports are constrained and his masterly analysis of both sides of a problem is so detailed that the conclusions are often weak and equivocal. They lack the imaginative spark which lights up and fires off great progress. In short, Tremenheere had many of the external qualities which are caricatured in the modern civil servant although, of course, this genus was in 1850 hardly known.

Supremely adequate socially, although he rarely let himself go, he loved the opera, good conversation, and the company of men like Kay Shuttleworth or Horner at the dinner table. These characteristics, together with a pleasing appearance (Fig. 1), constituted the conciliatory manner which also commended

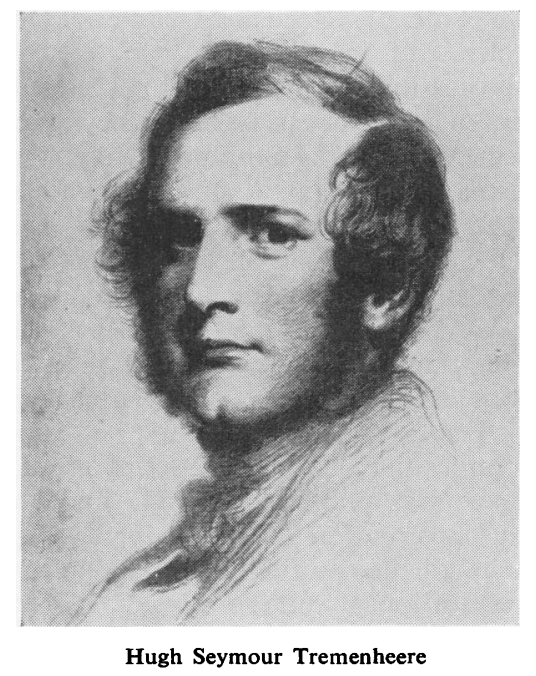

him to the Committee of Council on Education, and he was appointed their first inspector (salary $£ 500$ ) by Order in Council in December, 1839, turning down a lucrative offer of a law practice in Calcutta (salary $£ 3,000$ ).

He was first instructed to inspect the proposed site and structure of several schoolhouses in Monmouth and Hereford, whose sponsors had applied for government grant-in-aid. Having completed this task, he was about to return when he was diverted, in view of the recent Frost Rebellion in November, "to take this opportunity of enquiring into the state of education generally in that part of the country, and the nature of the superintendence under which it is placed". It was indeed a delicate task. Arriving as he 
did on December 24, 1839, Tremenheere describes in some detail the soldiers in the hotel and how they had fired on the mob. The populace at large believed that he was singling out one in $\mathbf{1 0}$ for execution by the government as a reprisal.

A second investigation followed almost immediately in Cornwall. Here, Tremenheere shows his skill in "sampling" by limiting his field of investigation to one portion only of each of the three chief mining areas in the country. Perhaps the most important feature of the report, other than his method of personal fact finding, is his detailed reference to the health of the miner vis-à-vis his work. $\mathrm{He}$ analyses the causes of death from the parish register at Redruth over the period July 4, 1839, to November 10,1840 , and relates them to occupation. He comments on the frequency of 'miners' consumption" (phthisis) and the low average age at death of the miner ( 43.2 years) compared with that of the general population (54.1 years). These and the high accident rate are specifically correlated to occupation, and it is clear that he had familiarized himself with conditions underground, possibly in person. If not, could he describe in such detail the task of the "tutworker" and the "tributer", their constrained positions at work, the use of the wedge for splitting stone, and the method of selling contracts of work? Although he dwells on the advantages of pithead baths and better ventilation in general, he accepts the predictability of occupational hazards and pleads for education so that in addition to the consolation of religion the miner might have "intellectual resources, a relief which would lighten the pressure of lingering disease hitherto apparently the almost inevitable lot that awaits him". Such education would provide "moral and spiritual improvement; not to raise the individual from his own sphere but to enable him to do his duty in that to which he belongs".

In this correlation of occupation and disease, Tremenheere was a pioneer, and his observations contrast strongly with the bland assurances currently given to the public elsewhere (Simonin, 1867). It is a great tribute to the scope of his reading that, although not medically trained, he was familiar with the recently published original treatise of Thackrah (1832), the acknowledged father of industrial medicine in England.

For two and a half years Tremenheere reported on schools in different parts of the country in his cold, factual, impersonal, and detailed way. The border line between fact and opinion, or implied criticism, is very indefinite, however, and his stringent report on the monitorial system in 66 London schools annoyed the British and Foreign School Society. Tremenheere, adamant and intransigent, refused to give way at all. "Show me a word that is wrong and I will alter it. Point out a single fact in which $I$ am in error and it shall be expunged." The outcome was inevitable and in his own words, "The British and Foreign Society were not likely to work harmoniously with the Government while I continued Inspector. Yet the Government could not with any justice set me aside; they had indeed supported me throughout with the utmost steadiness. It was necessary for them to provide me with some other employment which should be a promotion, before they proposed any new arrangements for inspection to the British and Foreign School Society". He went on, "This they have honourably done by offering me the Inspectorship of Mines and Collieries, with an additional salary of $£ 100$ a year, and the promise of Sir James Graham that I shall have the duty of attending to the District Schools as Assistant Poor Law Commissioner pro tem", adding almost in criticism, "how far this succumbing on the part of the Government (Conservative) to the dissenting body is politic or wise is another affair".

\section{H.M. Inspector of Mines}

Tremenheere's "promotion" to mines was not so abrupt a transition as appears at first sight. Just as schools were scattered in small units over the country and jealously guarded by local management committees of the two main voluntary societies, so were the mines equally dispersed with owners even more resentful of government interference. The method of inspection which he had evolved with Kay Shuttleworth was therefore equally applicable with the added problem of enforcing certain statutory regulations.

\section{His Enforcement of the Law}

It is a prime duty of the inspector to see that the law is obeyed. Tremenheere introduced two methods which although apparently contradictory, complement each other in practice. On the one hand he strove to achieve a personal informal bond of mutual trust between inspector and inspected through which persuasion and reason could prevail; on the other, he made effective the due process of law to deter the recalcitrant offender. He was on new ground, for up to 1843 there had been no compulsory statutory regulations relating to the health and safety of miners within the colliery.

With characteristic caution Tremenheere made a preliminary tour of the midland coalfield with letters of introduction to the coal owners. Then before visiting a colliery he circulated the substance of the Act of 1842 and "bespoke their co-operation" in implementing it. Relevant extracts from the Children's Employment Commission of 1842 accompanied the standard letter. After his visits 2,000 
copies of his Annual Report to Parliament were distributed to those people in the coalfields "nearly all of whom I have personally examined ... they comprise persons in all classes and opinion". Some of these practices still survive, e.g. the Ministry of Power Safety Regulation No. 247, recently available, explains the Draft First Aid Regulations 1962, and the Chief Inspector notes with approval that the National Coal Board distributed 44,000 copies and the National Union of Mineworkers an unspecified number of his Annual Report for 1961. Visits by inspectors have, however, been unheralded since 1878 for miners complained that notice gave opportunity for evasion of the law. Tremenheere's emphasis on an effective personal relationship based on visits and frequent communication between inspector and management would still be endorsed today.

It is doubtful how far personal persuasion can be effective without the potential sanction of the law, and Tremenheere quickly rectified the lack of effective administrative measures of enforcement of the statute. He employed policemen to watch the shaft mouth and paid local professional gentlemen 25 shillings per week to produce evidence leading to conviction. Not every offender was prosecuted. Persistent and wilful breaches of the Act after warning were punished but many cases were overlooked where the inspector's advice was subsequently heeded. He refused, on one occasion, to prosecute in Yorkshire where boys worked the thin seams, despite a peremptory note from the Under Secretary of State on his delinquency, and pointed out that their labour was essential to economic coal getting.

Prosecutions of management by H.M. Mines Inspectorate are few today but it still remains an effective and fearsome weapon in the eyes of the former, compelling obedience to the law. The discretionary power of the inspector to countenance exceptions to the statute still remains and is widely practised because of the range of conditions in mines and is carefully limited; that of Tremenheere stemmed from his personal authority and was not thus fettered. The attitude of fierce "lone wolf" independence was quickly assumed by subsequent divisional inspectors and in 1908, after the first chief inspector had been appointed, John Gerrard in Manchester and J. B. Atkinson in Northumberland, in their correspondence with him, made little attempt to disguise their aversion to central direction even when exercised for administrative purposes only (Bridgmore Brown, 1961). Despite this, the general correspondence between inspectors and the Home Office between 1850 and 1900 shows increasing effective central control and it is certain that no subsequent inspectors ever enjoyed the independence or the discretionary power of Tremenheere.

\section{His Fact Finding and Reporting}

Tremenheere's second major duty was to inquire into the condition of the mining community. His method was to question patiently all strata of society and read back their statements for verification. This was supplemented by perusal of any relevant documents, e.g. pay sheets and contracts of employment, copies of which are factually reproduced; there is little substance in the criticism of Martin Jude, one time secretary of the Miner's Association, that "Tremenheere did not come to get a correct report ... the Commissioner was shown over the houses these little bodies were living in, taken to the colliery office and courteously assisted to the station by officials; but the men were not in a single instance consulted" (Fynes, 1873). He actually attended a meeting of the miners' leaders at Newcastle in 1847 and was "always seeking interviews with the most violent of the agitators". No aspect, social, economic, or political was immune from his questions but he did not go underground at any time after his appointment as Director of Mines and there is no account of machinery or method of mining. This omission was not so much from choice as deference to the coal owners who had rigorously opposed any such comment when the Act of 1842 was debated in Parliament.

In addition to presenting the facts, Tremenheere commented freely, condemning or recommending according to what he felt was in the best interests of the miner. Many of his recommendations were subsequently adopted, e.g. reporting of fatal and serious accidents, the training of management in the art of management, and the responsibility of the employer to provide pithead baths and reasonable habitation for the men. His suggestion that the latter appoint a small committee to improve communication with the management might be construed as a blueprint of present-day joint consultative machinery. Tremenheere certainly thought that he "took both sides into my confidence and as it were brought them together through myself" but saw himself only as a means of communication. Consultation he would have regarded as an impediment to the free enterprise of capital essential for prosperity. His economic views and his constant praise of just, liberal management, detract from the value of his reports and contrast strangely with the stringent comments on the monitorial system of teaching which so offended the British and Foreign Schools Society.

H.M. Inspectors of Mines still issue annual reports and continue to supply reliable facts about the industry on which subsequent legislation is based. They confine themselves, however, to those affecting the health and safety of the men at work. There is no 
reference to strikes, to production, to unemployment, or to social activities of the community. The inspector's personal opinion is submerged in that of more general national policy. Nevertheless, although the content has changed, the principle of fact finding as a basis for action has survived as an important function of the inspector.

\section{Other Activities}

Tremenheere interpreted his mandate freely and even extended his activities within the mining community. After organizing a new water supply for the town of Airdrie by pushing a local Act through Parliament he proceeded to negotiate actively with local government officials, Members of Parliament, and Iron Masters, to promote a unified police force and re-organize the general administration of justice for Glasgow. His enthusiastic letter to $\mathrm{H}$. Manners Sutton, Under Secretary of State, dated January 17, 1845 , pointing out that the way is "now prepared for government intervention" earned him reproof for exceeding his terms of reference. A similar stricture applied to his local negotiation for abolition of arrestment of wages for a debt under $£ 8.1 \mathrm{~s}$. 8d. in 1845. Tremenheere apologized and allayed government fears, stating "I have repeatedly . . . taken occasion to explain that my interference in these matters was entirely on my own responsibility and unsuggested by the government"'. Sir James Graham, Home Secretary, was afraid that his inspectors might be regarded as snoopers or spies, a charge previously levelled at factory inspectors by Fielden in 1840. The identification of central inspectors with the government is, however, inevitable and must of necessity curtail their exploration of new fields. Tremenheere was unabashed and continued his activities within the community, particularly in the field of education, but subsequent inspectors gradually concentrated on safety and health within the colliery itself in line with the regulations of statutes, as they do today. This is probably inevitable, for the bigger the machine the more energy is directed to keeping it going rather than exploring what new work it can be doing.

\section{Discussion and Evaluation}

Tremenheere enforced the Act of 1842 to good effect with a judicious mixture of prosecutions and persuasions. $\mathrm{He}$ notes that the 2,400 women in Scotland and 800 in Lancashire, underground at that time, had fallen to 200 in each case by 1845 although odd prosecutions are recorded as late as 1858 . His fact finding and resultant recommendations contributed to later statute law. These are still two of the main functions of the present-day Mines Inspectorate, and Tremenheere's contribution to their develop- ment is often overlooked because little attention has been paid to the inspector's method as opposed to the content of his work. A former Chief Inspector of Mines and Quarries refers to Tremenheere as welfare officer not inspector (Bryan, 1950), largely because he was not a mining engineer and did not visit underground. It should be recalled that Tremenheere gives a splendid account of conditions and methods of underground work in his reports on education in Cornwall and was President of the Royal Geological Society there. He did in fact send two men underground in 1853 into a coal-mine but reports that they barely escaped with their lives. This review may serve to disperse misconceptions and indicate the contribution of Tremenheere to H.M. Inspectorate of Mines.

More important than what he did, however, is the influence of his recommendations for the future development of the Mines Inspectorate made at the request of the government and published in the Command Paper of the Inquiry into the Darley Main Disaster 1847. He did not envisage any increase in statutory regulations. The inspectors, each an individualist and a skilled mining engineer to whom appointment itself was a high honour, would assimilate and improve the best mining practices and by virtue of their personal qualities and technical skill persuade colliery management to adopt them. The inspectors would not interfere at all in management itself; should any dispute arise reference would be made to an independent arbitrator. The conviction that management would respond to these supermen and that the central government would permit them such independence is truly remarkable in the light of Tremenheere's own experience. There was, furthermore, strong pressure from the miners themselves for an inspectorate like that in the factories based on a veritable army of detailed law enforcers. Nevertheless, his influence was such that the Coal Mines Act of 1850 seems to crystallize his concept of an inspectorate and rightly enough he regarded it as one of the 15 Acts of Parliament to which he had made a major contribution. Inspectors were given authority to enter and examine coal-mines at all times and look into all matters relating to the safety of the people employed therein; they themselves must not be practising mine agents or owners; they were to receive notice of fatal accidents from the manager and attended inquests; they were to inspect the maps of mine workings which it was made incumbent for the manager to keep; they were to take no direct steps to promote education but use every opportunity to point out the advantages. Enforcement rested on their power to call the manager before them and advise him; if unsuccessful they were to report to the Secretary of 
State. A penalty of $£ 5$ to $£ 10$ is prescribed for obstruction or other breach of the Act. The inspectors received their instructions from the Secretary of State: "it will be your duty to enquire carefully into the state and condition of the collieries you will inspect in order to point out defects . . . it is no part of duty to enforce any particular mode of ventilation or working". Tremenheere could have asked for little more. Furthermore, it was he who prescribed the qualifications required of the inspectors. None of them had legal training or his social background, but they were all more experienced in mining techniques, e.g. Matthias Dunn had been a colliery manager at Workington in 1836, Joseph Dickenson had spent all his life in the coalfields of Newcastle, South Wales,and Scotland before his appointment in the Lancashire and North Wales Division, and J. K. Blackwell (1850) had only recently completed an investigation into accidents in coal-mines. It must be remembered that there was at this time no specific training or qualification in mining engineering and skill derived from practical experience and geological studies.

For five years these original six inspectors (two more were appointed in 1852) strove to persuade management, and their letters requesting installation of safety precautions or condemning unsatisfactory conditions are a model of politeness and courtesy. (Herein perhaps lay the germ of the complaint to be voiced for many years that they were tools of management.) Subsequently, an increasing number of the best mining practices were incorporated into the law. The Coal Mines Act of 1855 specified seven general rules to be observed in all coal-mines and made provision for special rules to be drawn up in all collieries. After approval by the Home Office, breach of these rules incurred a fine and/or imprisonment of three months. Another Act in 1860 increased the general rules to 16 and again in 1872 codifying legislation made provision for 31 such rules as well as a host of special rules for certain districts and collieries. This trend has continued and today the Mines and Quarries Act is a sizable volume comparing favourably with the Factory Act. The duty of the inspector to ensure adherence to these rules was specifically stated in 1860 . Clearly, as the number of rules multiplies, the field for exercise of creative function diminishes and the probability of prosecution for non-adherence to the rules increases; indeed, there are many more prosecutions after 1855 . It is significant, too, that after this date the inspector had, with increasing frequency, to seek the authority of the Secretary of State before initiating prosecution otherwise the Treasury might refuse to meet the solicitor's costs, i.e. the discretion and independence practised by Tremenheere was passing to the centre away from the inspector in the field. Matthias Dunn was fiercely rebuked for expressing his personal views on government inspection in The Economist. The Home Office also increased its control by indirect financial pressure. The rule that inspectors must not be practising viewers, land agents, or managers was enforced strictly against both Dunn and Dickenson. Few of the early inspectors had private means and they complained frequently of the inadequate salary. They were even driven to attending inquests in order to supplement their income by these professional fees. Then, too, close scrutiny of expenses afforded further opportunity for control and a request to all inspectors for a list of their daily activities was an inevitable conclusion.

This increase of statutory regulations and of central direction of inspectors Tremenheere would have regretted. His influence is seen, however, in the continued insistence of H.M. government on both technical mining and managerial experience in new appointments; in the absence of suitable candidates posts have remained unfilled. The equivalent of mill superintendent in the Factory Inspectorate has never been recognized; every appointee is potentially a chief inspector in terms of training and personal qualities required. This is related to function for the present day mines inspector is, as Tremenheere so often advised, "counsellor to both management and men" and not "guardian of public safety intent on punishment" (Bryan, 1950) although most will admit somewhat wryly that management has become more amenable to persuasion since nationalization. Further, the inspectorate does not interfere with detailed management of a colliery and comment is made only through the colliery manager. It is true, of course, that in the last resort the inspector can stop production of coal but the colliery manager may demand an inquiry subsequently, a relic of Tremenheere's arbitration procedure. Finally, it should be noted that every central government inspector, whether mine, school, or factory, and whatever he may do in practice, always likes to think of himself as an "itinerant ambassador of competence and goodwill, diffusing everywhere his intelligence and counsel without imposing directions". Tremenheere's greatest contribution to inspectorial method was the formulation of this ideal image in adverse circumstances 100 years ago. This justifies his title "Father of the Inspectorate" afforded him in The Royal Commission on Mines in 1938.

\section{Conclusion}

Tremenheere, as first inspector of both schools and mines, made a powerful contribution to central government inspection. In addition he made numerous investigations under the title of Commissioner 
into factories, and new legislation was based on his recommendations. Brief reference is made to these activities as they are inspectorial in nature and demonstrate his untiring capacity for work in the public service. In 1854 he personally investigated many bleaching and dyeing factories and his recommendations led to the Act of 1860 (23-24 Vict. c 78). A similar inquiry in 1869 made with E. C. Tufnell was followed by another Act in 1870 (33-34 Vict. c 62 ) in which both Factory and Print Work Acts were applied to the bleaching and finishing industry. His exploration of lace works led to the imposition of regulations in the Act of 1861 (24-25 Vict. c 117). Similar activity in bakehouses was followed by an Act of 1863 (26-27 Vict. c 40). He continued to receive reports about the working of this last regulation and published reports in 1865 and 1866, a truly inspectorial function. As senior commissioner of the investigation into the employment of children in industry and agriculture in 1862, his main role was rather the direction of others and collation of the results of their investigations which resulted in wider extension of the Factory Acts to many new industries and workshops and the licensing of labour on farms (Agricultural Gangs Act 1869 (30-31 Vict. c 130)). His efforts in the public service were acknowledged by the award of the C.B. on his retirement in 1871. He maintained his interest in the health and welfare of the working man right up to his death in 1893 , writing letters to The Times $(1871 ; 1873 ; 1879)$ about the adulteration of their bread or pleading for the repair of the agricultural labourer's cottage, and his political pamphlets for the Liberal Unionist Association were full of advice on how he should use his vote. He was indeed able to look back and with justification refer to a "full life".
I should like to thank Mr. C. B. Parker and Mrs. I. E. McNeill for affording access to the private papers and diaries of Tremenheere, now in the Morrab Library, Penzance. Original correspondence of inspectors with the Home Office, readily made available by the Public Record Office, was supplemented by valuable assistance from Mr. G. Bridgmore Brown, formerly Assistant Secretary (Safety) at the Headquarters of the National Coal Board, and previously of the Ministry of Power.

\section{REFERENCES}

Blackwell, J. K. (1850). Cmd (1214) H.M.S.O., London.

Boyd, R. N. (1879). Coal Mines Inspection. Allen, London. Brown, Bridgmore (1960). Sheffield University Mining Magazine, 34 Brown, Bridgmore (1960). Sheffication.

Bryan, A. M. (1950). Trans. Instn. Min. Engrs., 109, 875.

Buess, H. (1962). Brit. J. industr. Med., 19, 297.

Minutes of the Committee of Council on Education (1839-45). 13 Reports on Schools by H. S. Tremenheere.

Dunn, M. (1854). History of the Steam Jet, H.M.S.O., London.

Fynes, R. (1873). The Miners of Northumberland and Durham, p. 141 Robinson, Blyth.

Morrah, Dermott (1927). Historical Review of Coal Mining, Fleetway Press, p. 301

Simonin, L. (1867). La Vie Souterraine. Hachette, Paris. Trans. H. W. Bristow, as Mines and Miners Mackenzie, London. 1869.

Thackrah, C. T. (1832). The Effects of Arts Trades and Professions on Health and Longevity, with an introductory essay by A. Meiklejohn (1957). Livingstone, London.

The Times (1871). August 25 and October 6.

ibid (1873). February 3 .

ibid (1879). May 26

Tremenheere, H.S (1852a). The Political Experience of the Ancients, in its bearing upon Modern Times. Murray, London.

(1852b). Notes on Public Subjects, made during a Tour in the United States and Canada. Murray, London.

(1854). The constitution of the United States compared with our 1854). The constitution of
own. Murray, London.

own. Murray, London.
1866). Translations from Pindar into English Blank Verse. Moxon, London.

(1883). A Manual of the Principles of Government, 3rd ed. Kegan, Paul, London.

(1888) Disestablishment and Disendowment. S.P.C.K., London. (1890). Why have I a vote? and how should I use it? Liberal Unionist Association, London.

- (1891). A New Lesson from the Old World. Speaight, London. (1893) How good government grew up and how to preserve it. Liberal Unionist Association, London.

Tremenheere, S. G. (1925). The Tremenheeres. London. Private

Tufnell, E. Carlton (1833). P.P., xx, L. 